

\title{
New Lexicon Adaptation in the Development of Creative Tourism
}

\author{
Luh Eka Susanti \\ Institut Pariwisata dan Bisnis Internasional \\ ekasusanti@ipb-intl.ac.id
}

\begin{abstract}
How to cite (in APA style):
Susanti, L. E. (2021). New Lexicon Adaptation in the Development of Creative Tourism. Retorika: Jurnal Ilmu Bahasa, 7(2), 152-156. doi: https://doi.org/10.22225/jr.7.2.3893.152-156
\end{abstract}

\begin{abstract}
This article describes a number of new language terms in their development in the world of creative tourism, especially for tourists. This term arose as a result of the growing and varied types of new tourism that emerged because of the need to relieve boredom from the fatigue of daily routines. In addition, the use of this term is also inseparable from the development and proliferation of the use of social media among the global community. Even these terms are increasingly embedded in the minds of tourists and the surrounding community so that all elements of creative tourism are now commonplace in using this language variation which is very influenced with the changing needs of tourists. Generally, this language term is a combination of two words that refer to new meanings in the needs of contemporary creative tourism.
\end{abstract}

Keywords: Creative tourism, Language terms, Social media

\section{INTRODUCTION}

There are several alternative activities to relieve fatigue and boredom from the hectic and monotonous daily activities, one of which is traveling. Traveling is a person's journey to a different place and has never been visited which contains curiosity, knowledge, pleasure, challenge, and experience. Generally, when viewed from the planning, there are tours that are planned long in advance or without careful planning. Traveling does not always have to be abroad to visit neighboring countries or distant countries on different continents, this can also be done in your own country. Many places in Indonesia are places of recommendation and reference for travel, be it artificial tourism or natural tourism.

Traveling does not have to be done in groups, either with friends, partners, or family, but this can also be done individually (individually). Traveling with friends, partners, or family does provide its own benefits, but there are more portions to share in several things such as finance, accommodation, transportation and even sharing stories or experiences while traveling. On the other hand, traveling independently (solo traveling) will provide a different essence when compared to traveling with other people. This is because anything will be done independently and rely more on yourself. But behind that, curiosity and mingling with the surrounding environment will be greater if you carry out travel activities individually.

Tourism synergizes with a number of aspects, such as cultural, economic, social, and technological developments. Along with the development of technology, tourism is able to show its existence by adapting to a modern mindset so as to create more varied types of 
tourism. This is also motivated by the saturation of tourists with the types of tourism or tourism destinations that are monotonous. With the development of technology which has an impact on the emergence of a number of social media platforms, such as Facebook, Instagram, Tiktok, etc. Even when traveling, social media will certainly be used as a place to show off, or just as a means to show one's existence.

In addition, along with the development of technology, the creation of a new lexicon or vocabulary that describes how tourism is. The lexicon is generally in English which consists of a combination of several words that have existed before so that they have new meanings, or words that arise due to the influence of social media. Even today, the lexicon is very commonly used and can be easily understood. The lexicon also describes creative tourism that is able to illustrate activities or activities in traveling in a new way. Some of these lexicon include staycation, babymoon, cinetourism, instagrammable, gray nomad, and so on.

\section{LITERATURE REVIEW Tourism Concept}

Tourism is closely related to the culture of a particular area. In general, tourism is defined as a travel activity that is carried out temporarily from the original place of residence to the destination area for reasons not to settle or earn a living but only to have fun, fulfill curiosity, spend leisure time or vacation time and other purposes (UNESCO, 2009). Based on this definition, tourism is explicitly connected with activities and feelings for fun, diverting fatigue from daily routines or with other goals. In addition, according to UU No. 9/1990 on Tourism, what is meant by tourism is various kinds of tourism activities and supported by various facilities and services provided by the community, entrepreneurs, the Government, and Local Governments. Therefore, a person or more who travel and carry out activities related to tourism are called tourists. According to Helpiastuti (2018), tourists can be grouped into two, namely domestic tourists and foreign tourists. Domestic tourists are tourists who are Indonesian citizens who travel while foreign tourists refer to tourists who are foreign citizens (Non-Indonesian) who travel. To develop tourism activities, tourist destinations must at least have the following components (UNESCO, 2009):

1. Attractions and attractions

2. Transport and infrastructure
3. Accommodation

4. Food and beverage business

5. Other supporting services (eg public services, travel agencies, money changers, etc.).

The tourism concept must be based on three factors (Yoeti, 1985), namely something to see, something to do, and something to buy. These three factors

a) Something to see

The destination must have something that can be seen or made spectacle by tourists. In other words, the object must have a special attraction that can attract tourists to visit.

b) Something to do

Tourists who carry out these tourism activities can carry out activities to give a feeling of pleasure, happiness in the form of recreational facilities such as playgrounds or places to eat, especially the typical food of the place so as to make tourists feel more at home to visit there.

c) Something to buy

Everything to support tourist activities such as facilities for shopping tourists which in general are the hallmark or icon of the area, so that they can be used as souvenirs of the area.

The concept of tourism above must be able to be applied properly. When it has been developed and implemented in detail and comprehensively, the economic structure will clearly lift itself up. The more tourists visit the tourist location area, the manager's role will be maximized. Infrastructure facilities, such as toilets, parking lots, and other services will attract rupiah revenue in the regional treasury.

\section{Creative Tourism}

Every region that seriously develops the tourism sector and creative economy will experience direct impacts, such as increasing welfare and reducing the number of job seekers (Prakoso \& de Lima, 2019). From this statement, it is necessary to develop and develop superior products in the tourism sector and the creative economy in each of these regions. However, the development of the tourism sector is also hindered by a number of obstacles or problems that must be overcome to 
improve the quality of tourism and the creative economy. The problems experienced by the tourism sector include infrastructure, destination development, expansion of domestic and foreign tourism markets, institutions, and human resources and the problems experienced by the creative industry sector are in terms of creative industry development, business climate, product market expansion. creative, technology and content, both natural and human resources, and access to financing for creative economy actors.

Creative tourism can bring positive changes in a community in a country (Cidhy, et al, 2016). Although creative tourism is often associated with cultural tourism, the two are actually very different. Cultural tourism focuses on seeing, feeling, and contemplating. While the focus of creative tourism is the authentic experience experienced by tourists. In introducing new tourism and to find out how to attract tourists to visit, there must be a strategy from the manager to introduce and retain potential tourists.

In addition to cultural factors, the other most important thing that can attract tourists to visit is the level of uniqueness. The more unique the tourist attractions will attract consumers to visit. This is in line with the contents of Law No. 10 of 2009 tourist attraction is explained as anything that has uniqueness, convenience, and value in the form of diversity of natural, cultural, and man-made wealth that is targeted or visited by tourists. In Law no. 9 of 1990 concerning tourism, it is stated that a tourist attraction is something that is a tourist target. There are 3 types of tourist attractions in general, including:

1. natural tourist attraction created by God (mountains, lakes, flora and fauna)

2. the attraction of human creations in the form of museums, historical relics, arts and culture, agro tourism, hunting tours, recreation parks and entertainment complexes.

3. special interest tourist attractions, such as hunting, industry and crafts, shopping areas, fast-flowing rivers, places of worship, places of pilgrimage and others.

\section{English Planning in Tourism}

The development of tourism will have an effect on the lives of local people. These effects affect various aspects of life, be it social, economic, cultural, religious, and environmental (Sutarma \& Sadia, 2013). The extent of the influence of tourism development on aspects of life can be studied independently. This can be seen from the analysis of the influence of tourism on the social, economic, cultural, language development fields and other fields. When viewed from the development of the language used, generally used is a foreign language used globally in the world of tourism, namely English.

Kridalaksana in Sutarma \& Sadia (2013) suggests language planning as an effort to improve language communication by creating new subsystems or perfecting them, according to the needs of the community. Furthermore, it is explained that the standardization of terminology in the fields of life is an example of language planning. Other sources also mention that this language planning from the point of view of the form is often also called language treatment. What is meant by language treatment is how the speakers will provide language forms in a morphological and syntactic process. Henceforth, this article will contain and describe the emergence of a new lexicon as a result of the relationship between tourism development and the use of English.

\section{The Emergence of a New Lexicon in the Development of Creative Tourism}

According to (Gaho \& Sari, 2021), lexicon is a set of term. The lexicon plays a central role in defining the language of tourism as a special language, as well as in shaping different texts for promotional purposes (Lestari, et.al, 2021). It is in line with (Gaho, 2020) that language is also used in a certain purposes such as promoting. Promotional language involves two processes of interaction, communication and persuasion, which are usually found in advertising. The aim is not only to provide useful information, but also to lure and entice potential tourists to visit the area described. Text promoting a destination or tourist destination on websites or social networks is rich in foreign terms and words (usually in English) that define a particular product or service.

In the emergence of a new lexicon in the development of creative tourism, it can be seen from several meaning formations, including 1) blending (a combination of 2 words into 1 word that gives rise to a new meaning), 2) new word (a lexicon that arises due to the development of another aspect that affects tourism itself), 3) new meaning (the pairing of 2 separate words to create a new meaning). 


\section{METHODS}

This research is descriptive qualitative using primary data directly obtained from data sources, namely tourism advertisements about a tourist destination, certain products or services used on websites or social networks (Facebook and Instagram Ads). The data were collected using the observation method, which can be compared to the observation or observation method in social science, which is then explored or analyzed more deeply in terms of the meaning and purpose of its use.

\section{RESULT AND DISCUSSION}

There are several new lexicons that have emerged that have new meanings in the development of creative tourism, especially in promoting a tourist destination or tourism product. Below is a list of a number of new lexicons that have emerged as a result of the development of creative tourism.

1. Blending words (combining 2 words into 1 and having a new meaning), some of which are:

\section{a) Glamping}

Glamping or Glamorous Camping is currently emerging as a tourist trend for travelers who like nature, without forgetting the comfort factor. This word is very familiar among tourists today who want to enjoy nature by camping and being close to nature but in a slightly different way. Similar to camping, glamping is a tourist activity looking for exciting experiences by staying on the beach, hills or hiking. However, glamping usually provides facilities that tend to be luxurious. Starting from a comfortable bed in the form of a spring bed, a bathroom with shower and hot water, to a TV.

b) Cinetourism

As its name, cinetourism is a combination or blending words of 2 words, namely cinema and tourism. Cinetourism can be in several types of travel related to films, for example by visiting film museums, or experiencing the sensation of watching in unique cinemas around the world or by traveling to places where the location has been used as a filming location. Generally, cinetourism will take the location for the process of making famous films.

c) Staycation

Literally, a staycation (from the words 'stay' and 'vacation') can be interpreted as a temporary vacation in or around a resident tourist. Generally temporary, only 1 night. So that tourists do not need to travel too far and don't need too much time, just take advantage of weekends like Saturday and Sunday. Nowadays, this term is widely used by accommodations such as hotels and villas to promote their tourism products on social networks in the form of Facebook or Instagram Ads to spend some time to relieve fatigue from daily routines.

d) Mancation

Mancation is a type of traveling tour intended specifically for men only, where there are no women who participate in this activity. Generally, the types of activities carried out are more extreme and challenging such as doing water sports, mountain climbing, fishing with spears. In this activity, because it is only attended by men, they are generally allowed to drink alcohol in large portions.

2. New word (lexicon that appears as a result of the development of another aspect that affects tourism itself)

a) Instagrammable

This word emerged as a result of technological developments and the proliferation of social media (Instagram) which also resulted in the development of creative tourism. This application was created to meet the needs of tourists and millennial to take pictures and provide a platform for them to show their existence or just show off. Along with the development of new types of tourism, the term instagrammable refers to locations to take pictures in tourist destinations that are considered unique and capable of producing good and interesting screenshots to be uploaded to tourists' social media.

3. New meaning (pairing 2 separate words to bring up a new meaning).

a) Babymoon

Babymoon consists of 2 words that 
initially stand alone (baby and moon) and have different meanings after being juxtaposed. Babymoon is often interpreted as a romantic trip or vacation with a beloved partner before the arrival of the baby into the world. Even though the concept is just a trip or a vacation together, babymoon provides many benefits for mothers, fetuses, and prospective fathers to enjoy togetherness in a different atmosphere. This activity can be an opportunity to rest, discuss, and strengthen the bond between you and your husband. The bond that is established before the birth of the baby is very important, so that prospective parents are better prepared for their new roles. It's no wonder that now babymoons are increasingly being carried out by prospective young parents.

b) Gray Nomad

Gray nomad is a type of tourism that emphasizes adventurous activities without a definite destination. Literally, gray nomad consists of two independent words, namely gray and nomad. The meaning of the color gray which is likened to uncertainty between several color choices refers to a tourist trip that is not necessarily in a direction, while nomad comes from the word nomadic which means to move around. Therefore, gray nomads are synonymous with tourists who travel uncertainly and generally last for a relatively long period of time so that tourists will use a van complete with a tent.

\section{CONCLUSION}

The development of tourism, especially in creative tourism, has the potential to bring about changes in other sectors, in this case related to the emergence of new lexicons in introducing or describing creative tourism itself. Along with technological developments and the emergence of social media platforms that support the development of creative tourism, language also gives birth to new terms or lexicon that are formed because 1) blending words (a combination of 2 words into 1 word that gives rise to new meanings), 2) new words (a lexicon that creates a new meaning). Arises as a result of the development of another aspect that affects tourism itself), 3) new meaning (combination of 2 separate words to create a new meaning).

\section{REFERENCES}

Cidhy, D.A.T.K, Baga, L.M. \& Djohar S. (2016). Pariwisata Kreatif dan Kegiatan Ekstrakurikuler Berbasis Bambu dalam Pengembangan Model Bisnis CV Suratin. Jurnal Manajemen \& Agribisnis, Vol. 13 No. 3

Gaho, R. (2020). What's up with Vocabulary and Grammatical Use in News Texts? Konferensi Tahunan Atma Jaya, 325-331.

Gaho, R., \& Sari, R. P. (2021). The Existence of Fauna Lexicon in the Elefu Song Lyrics Composed by Hikayat Manao: Ecolinguistics Study. International Seminar on Social Science, Humanities, and Education (ISSHE), 1(1).

Helpiastuti, Selfi Budi. (2018). Pengembangan Destinasi Pariwisata Kreatif Melalui Pasar Lumpur. Jurnal of Tourism and Creativity. FISIP Universitas Jember. Vo. II No. 1

Lestari, Denok, et.al. (2021). Rona Bahasa dalam Pariwisata. IPB Internasional Press

Prakoso, A.A \& de Lima,Y.A. (2019). Strategi Pengembangan Pariwisata Kreatif Berbasis Masyarakat (Communitybased Creative Tourism) Di Bintan. Journal of Tourism and Creativity. Vol.3 No.2 Juli 2019. ISSN: 2549-483X.

Sutarma. I.G.P, \& Sadia, Ketut.(2013). Penggunaan Bahasa Indonesia di Industri Pariwisata: Studi Kasus Perencanaan Bahasa pada Industri Pariwisata Bali. Soshum Jurnal Sosial dan Humaniora, Vol. 3, No. 2, Juli 2013.

UNESCO. (2009). Panduan Dasar Pelaksanaan Ekowisata.

Yoeti, Oka A. (1985). Pengantar Ilmu Pariwisata, Bandung: Angkasa 